
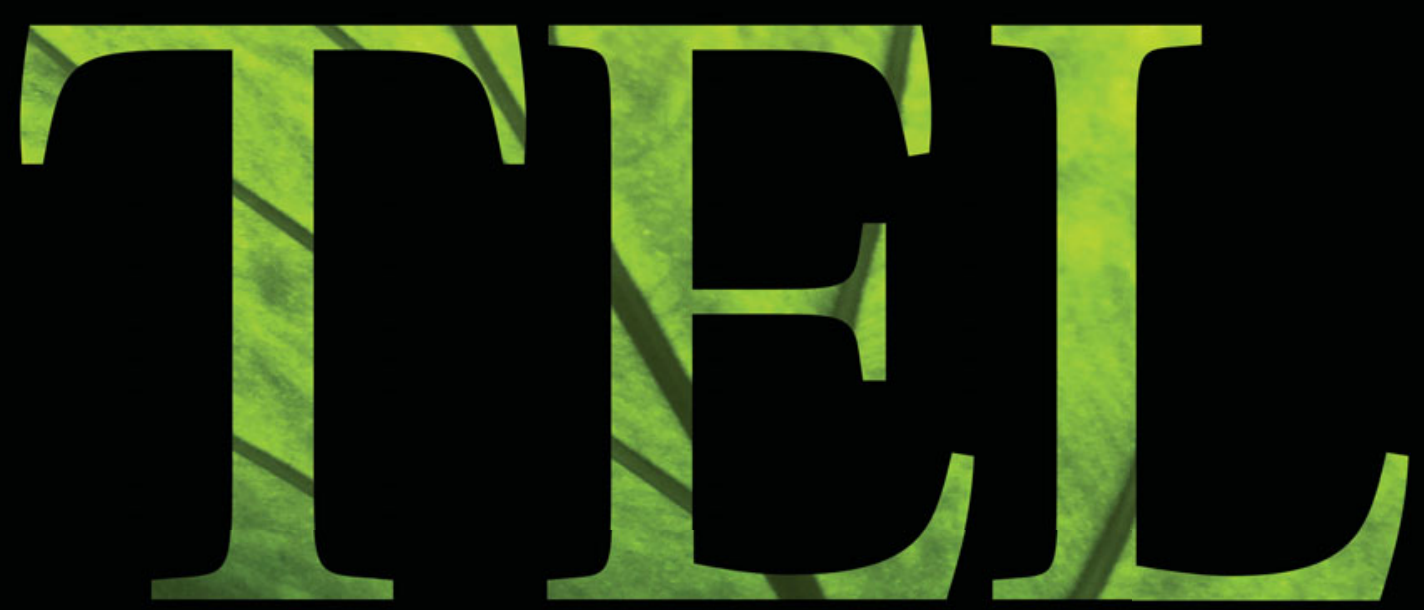

TRANSNATIONAL ENVIRONMENTAL LAW 


\title{
Transnational Environmental Law
}

\author{
EDITORS-IN-CHIEF \\ Thijs Etty, VU University Amsterdam, \\ Institute for Environmental Studies (IVM), \\ De Boelelaan 1087, Amsterdam, 1081 HV, The Netherlands \\ Email:Thijs.Etty@vu.nl \\ Veerle Heyvaert, London School of Economics and Political Science, \\ Department of Law, Houghton Street, London, WC2A 2AE, United Kingdom \\ Email:V.Heyvaert@lse.ac.uk
}

\section{EDITORS}

Cinnamon Carlarne, Obio State University, USA

Daniel Farber, University of California - Berkeley, USA

Jolene Lin, University of Hong Kong, Hong Kong Joanne Scott, University College London, UK

\section{Assistant EDITORS}

Louis Kotzé, North West University, South Africa

Mihalis Kritikos, Vrije Universiteit Brussels, Belgium

Kati Kulovesi, University of Eastern Finland (UEF), Finland

Natasha Affolder University of British Columbia, Canada

Edith Brown Weiss Georgetown University, USA

Geert Van Calster K.U. Leuven and DLA Piper, Belgium

Jonas Ebbeson Stockholm University, Sweden

Daniel C. Esty

Yale University, USA and Connecticut

Department of Environmental

Protection, USA

Francesco Francioni European University Institute, Florence, Italy

Neil Gunningham Australian National University, Australia

Ellen Hey

Erasmus University Rotterdam, The Netherlands

Stephen Humphreys

London School of Economics, UK

Koh Kheng Lian

National University of Singapore, Singapore

\section{AdVISORY BOARD}

Ludwig Krämer Derecho y Medio Ambiente, Spain and University College London, UK

Douglas A. Kysar Yale University, USA

Maria Lee University College London, UK

Yoshiko Naiki Osaka University, Japan

Robert V. Percival University of Maryland, USA

Lavanya Rajamani Centre for Policy Research, New Delhi, India

Richard L. Revesz New York University, USA

Benjamin J. Richardson University of British Columbia, Canada

Gregory Shaffer University of Minnesota, USA

Wang Xi Shanghai Jiao Tong University, China

\section{Statement of Aims}

Transnational Environmental Law (TEL) is a peer-reviewed journal for the study of environmental law and governance beyond the state. It approaches legal and regulatory developments with an interest in the contribution of non-state actors and an awareness of the multi-level governance context in which contemporary environmental law unfolds.

TEL offers a forum for rigorous analysis and discussion of the impacts of globalization on complex environmental risks and norms. It welcomes scholarship that enriches our understanding of contemporary environmental law through comparative and cutting-edge interdisciplinary analysis. TEL's scope is broadly conceived in terms of disciplinary focus: its pages are open to scholarly contributions covering a wide range of environmental issues, including climate change, biodiversity, emerging technologies, industrial pollution and waste management. TEL also promotes the exploration of the evolving dynamics between environmental law and other legal disciplines (including but not limited to trade and competition law, financial law and human rights).

TEL strives for a new generation of environmental scholarship that will bridge geographical boundaries, scholarly styles and generations. TEL encourages the integration of theoretical and practical legal perspectives on current environmental issues, and aims to deliver scholarship of high salience to academics and practitioners alike. 


\title{
TRANSNATIONAL ENVIRONMENTAL LAW
}

\section{VOLUME 3 ISSUE 1 APRIL 2014}

\author{
Contents
}

\section{EDITORIAL}

1-6 Contesting Assumptions and Unmasking Myths: Key Components of the Mission and Methodology of Transnational Environmental Law Thijs Etty and Veerle Heyvaert, Editors-in-Chief Cinnamon Carlarne, Dan Farber, Jolene Lin, Joanne Scott, Editors

\section{SYMPOSIUM: GLOBAL CLIMATE GOVERNANCE WITHOUT THE US}

7-15 Symposium Foreword: 'Go Ahead Without Us': Global Climate Change Policy in the Absence of Full Participation Joanna Dafoe and Douglas A. Kysar

17-29 Inside the System, Outside the Box: Palau's Pursuit of Climate Justice and Security at the United Nations Stuart Beck and Elizabeth Burleson

31-55 Climate Policy and the United States System of Divided Powers: Dealing with Carbon Leakage and Regulatory Linkage Daniel A. Farber

57-88 Strengthening the Transnational Regime Complex for Climate Change Kenneth W. Abbott

89-110 Climate Engineering in Global Climate Governance: Implications for Participation and Linkage Edward A. Parson

111-125 US Federal Climate Change Law in Obama's Second Term Michael B. Gerrard and Shelley Welton

\section{ARTICLES}

127-147 Change and Subjectivity in International Environmental Law: The Micro-Politics of the Transformation of Biodiversity into Genetic Gold Andreas Kotsakis

149-172 Public Access to Environmental Information: A Comparative Analysis of Nigerian Legislation with International Best Practice Uzuazo Etemire 


\section{BOOK REVIEWS}

173-189 Review Essay: Pluralism, Informality and Transnational Environmental Law Harro van Asselt

191-195 The Ethics of Global Climate Change, edited by Denis G. Arnold A Perfect Moral Storm: The Ethical Tragedy of Climate Change, by Stephen M. Gardiner Climate Ethics: Essential Readings, edited by Stephen M. Gardiner, Simon Caney, Dale Jamieson \& Henry Shue

Ethical Adaptation to Climate Change: Human Virtues of the Future, edited by Allen Thompson \& Jeremy Bendik-Keymer Reviewed by Benoît Mayer

195-200 Environmental Policy in the EU: Actors, Institutions and Processes, 3rd edn, edited by Andrew Jordan \& Camilla Adelle The External Environmental Policy of the European Union: EU and International Law Perspectives, edited by Elisa Morgera Reviewed by Ludwig Krämer

201-227 Highlights of Recent Book Publications 